\title{
Application of a Undaria pinnatifida for industrial cultivation of Lactobacillus
}

\author{
Bo Yoon Chang ${ }^{1}$, Ji Hye Han ${ }^{1}$, Ju-Hee Kim², Bum-Suk Cha ${ }^{2}$, Sung-Ho Ann ${ }^{2}$, \\ Sung Yeon $\mathrm{Kim}^{1 *}$ \\ ${ }^{1}$ Institute of Pharmaceutical Research and Development, College of Pharmacy, Wonkwang University, Iksan 570-749, Korea \\ ${ }^{2}$ Young Science Scharlau Korea, Jeonnam Biotechnology Research Center, Hwasung 519-801, Korea
}

\section{유산균의 산업적 배양을 위한 미역의 유용성 평가}

\author{
장보윤 ${ }^{1} \cdot$ 한지혜 $^{1} \cdot$ 김주희 $^{2} \cdot$ 차범석 $^{2} \cdot$ 안성호 $^{2} \cdot$ 김성연 $^{1 *}$ \\ ${ }^{1}$ 원광대학교 약학대학 약품연구소, ${ }^{2}$ 영사이언스샬라우코리아
}

\begin{abstract}
To optimize the medium composition of Undaria pinnatifida as a pH modulator the growth of Lactobacillus plantarum industrial scale, we analyzed the $\mathrm{pH}$ and growth characteristics of $L$. plantarum in basal medium. Subsequently, the medium compositions addition of carbon, nitrogen sources and buffering agents were optimized. When $0.5 \%$ yeast extract and $2 \%$ glucose, $L$. plantarum grew to maximum cell density in experimental condition. However, the growth of $L$. plantarum rapidly $\mathrm{pH} 4.0$ in basal medium. A high alkali-ash value and low cost-effective utilization $n$ the waste part as examined. ddition of $U$. pinnatifida extract alleviated the serious decrease. Among them, juice of $U$. pinnatifida was most helpful for the growth of $L$. plantarum $\left(36.3 \pm 1.810^{8} \mathrm{CFU} / \mathrm{mL}\right)$. These results show that $U$. pinnatifida be large-scale cultivation of $L$. plantarum. This optimized $U$. pinnatifida medium can be used for safe and economical production of Lactobacillus.
\end{abstract}

Key words : Lactobacillus, medium, Undaria pinnatifida, industrial cultivation.

\section{서 론}

유산균은 직접 혹은 간접적으로 식품에 첨가되어 식품의 풍미와 조직을 개선하기 때문에 동서양을 막론하고 유제품 및 발효식품의 가공에 유용한 보조 수단으로 이용된다. 기 능적인 측면으로는 배변 촉진, 위 자극에 대한 보호, 면역기 능 강화 및 기타 특정 장 기관의 기능 강화 등의 효과가 입증 되었다. 이러한 과학적 근거를 바탕으로 유산균 시장 은 기능성식품, 의약품, 화장품, 생균제(probiotics) 및 동물 사료에 이르기까지 그 응용범위가 넓어지고 있으며, 성장

*Corresponding author. E-mail : sungykim@wonkwang.ac.kr Phone : 82-63-850-6806, Fax : 82-63-853-6821

Received 6 February 2015; Revised 26 March 2015; Accepted 30 March 2015.

Copyright (c) The Korean Society of Food Preservation. All rights reserved.
가능성이 매우 큰 시장으로 평가되고 있다 $(1,2)$.

유산균은 실험실과 같이 소규모로 배양하는 경우, 편의 를 위하여 Man, Rogasa, Shapre(MRS) 같이 제조회사에서 미리 조성을 맞춘 배지를 사용한다. 그러나 이러한 시판 배지는 대량배양에 적용하기에는 단가가 높아 산업 규모에 서 배지의 가격대비 효율성을 높이기 위해 질소원, 단백질, 펩타이드, 영양 성분 및 미량의 무기물을 기본량으로 첨가 하여 사용한다.

또한, 유산균을 고농도 배양하기 위해서는 배지 내의 $\mathrm{pH}$ 를 일정 수준 이하로 떨어지지 않게 $\mathrm{NaOH}$, 또는 $\mathrm{NH}_{4} \mathrm{OH}$ 등과 같은 알칼리를 첨가하여 일정 $\mathrm{pH}$ 를 유지시켜 주거나 신선한 배지로 계속 치환해주는 등 여러 가지 방법을 사용 하고 있다 $(3,4)$.

그러나 이러한 $\mathrm{pH}$ 조절제의 사용은 배양액 내 이온강도 를 지속적으로 증가시켜 균의 활력과 증식을 감소시킬 뿐만 아니라 많은 양의 알칼리 용액의 첨가로 인하여 배양액이 
희석되므로 균의 생화학적 환경변화를 가져올 수 있다(5). 따라서 이와 같은 $\mathrm{pH}$ 조절 방법을 이용할 경우 유산균의 효율적인 고농도 균체를 얻는데 한계가 있다.

김, 미역, 다시마와 같은 해조류에는 칼륨 이온이 많이 함유되어 있어 우수한 알칼리 식품으로 활용되고 있다. 그 중 미역은 우리나라에서 생산되는 양은 가식부를 기준으로 연간 약 50만여 톤에 이르고 있으나, 가식부 양의 약 40 50\%에 이르는 뿌리, 줄기, 어린잎, 포자엽 등은 미역 폐기물로서 그대로 바다에 투기되고 있다 $(6,7)$.

폐기되는 이러한 미역의 활용 예는 극히 드물고, 미생물, 특히, 유산균 배양용 배지에 사용한 사례 또한 보고된 바 없다. 따라서 본 연구는 폐기되는 미역을 미생물 배양용 배지, 특히, 유산균 배양용 배지에 있어 종래 $\mathrm{pH}$ 조절을 위해 완충액으로 첨가되는 합성 화학물질을 대체하여 활용 할 수 있는 방안을 제시하고자 한다.

\section{재료 및 방법}

\section{미역 첨가물 제조}

전라남도 완도군에서 2013년 3월에 생산된 건조 상태의 미역(U. pinnatifida)을 사용하였다. 미역 추출물은 분쇄한 미역을 $1 \%$ 로 물과 혼합한 후 미역의 점성이 추출되지 않는 온도 조건인 $60,80^{\circ} \mathrm{C}$ 에서 각각 30 분 또는 60 분 동안 가열 후, 원심분리하여 상등액을 사용하였다. 미역 착즙액은 분 쇄한 미역을 $1,5,10 \%$ 로 물과 혼합한 후 $80^{\circ} \mathrm{C}$ 에서 30 분간 가열 후 착즙 후 원심분리 하였다. 미역분말은 건미역을 분쇄기를 이용하여 $40 \mathrm{mesh}$ 의 입자크기로 분쇄하였다.

추출액과 착즙액은 액상 상태의 용매로 사용하였으며, 분말의 경우에는 분말의 상태로 첨가하였고 배지 제조시 용매는 증류수를 사용하였다.

\section{균주 및 배지}

연구에 사용한 $L$ plantarum 균주는 한국 미생물보존센터 (KCCM 11322, ATCC 8014)으로 부터 분양 받았고, MRS 배지에서 3회 이상 계대배양을 거쳐 glycerol stock법으로 $-70^{\circ} \mathrm{C}$ 에 균주를 보관하였다. 배양배지는 공개되어 있는 기존 유산균 생산업체의 자료를 기본으로 고가의 성분을 제외한 기본 영양배지 제조 후(Table 1) 탄소원, 질소원 및 미역의 조성을 달리하여 제조한 배지를 사용하였다. 모든 배지는 $121^{\circ} \mathrm{C}$ 에서 15 분간 멸균하였다.

\section{유산균 증식}

균수의 배양시간에 따른 증식을 조사하기 위해 생균수, 흡광도, 및 $\mathrm{pH}$ 변화를 배양 $0,6,12,18,24$ 시간에 측정하였 다. 생균수는 균배양액을 $0.1 \%$ 생리식염수로 10 배씩 연속 적으로 희석시키고, 그 희석액 $1 \mathrm{~mL}$ 에 plate count agar 9
$\mathrm{mL}$ 을 혼합하여 pour method로 확인하였다. 흡광도 측정은 spectrophotometer를 이용하여 일정시간에 따라 채취한 배 양액을, 생리 식염수를 이용하여 10 배 희석한 후 $600 \mathrm{~nm}$ 에 서 측정하였다. 배양에 따른 $\mathrm{pH}$ 는 변화를 측정하기 위하여 $10 \%$ 암모니아수로 $\mathrm{pH}$ 를 5 로 조절한 배지 및 $\mathrm{pH}$ 보정없이 미역이 첨가된 배지들의 배양하면서 $\mathrm{pH}$ 를 측정하였다.

Table 1. Effect of various culture media composition on the cell growth of L. plantarum

\begin{tabular}{lccccc}
\hline Components (\%) & Basal medium & Test 1 & Test 2 & Test 3 & Test 4 \\
\hline Glucose & 2.0 & 2.0 & 1.0 & 1.0 & 2.0 \\
Yeast extract & 1.5 & 1.0 & 1.0 & 0.5 & 0.5 \\
Casein & 1.0 & - & - & - & - \\
$\left(\mathrm{NH}_{4}\right)_{2} \mathrm{SO}_{4}$ & 0.5 & 0.25 & 0.25 & 0.25 & 0.25 \\
$\mathrm{KH}_{2} \mathrm{PO}_{4}$ & 2.0 & 0.1 & 0.1 & 0.1 & 0.1 \\
$\mathrm{~K}_{2} \mathrm{HPO}_{4}$ & 2.0 & 0.1 & 0.1 & 0.1 & 0.1 \\
$\mathrm{MgSO}_{4}$ & 0.01 & - & - & - & - \\
$\mathrm{Na}_{2} \mathrm{HPO}_{4}$ & 1.0 & 0.05 & 0.05 & 0.05 & 0.05 \\
Vitamin C & 0.8 & - & - & - & - \\
Tween 80 & 0.1 & 0.05 & 0.05 & 0.05 & 0.05 \\
\hline $\mathrm{CFU} / \mathrm{mL}\left(10^{8}\right)$ & $4.2 \pm 0.2$ & $3.9 \pm 0.6$ & $1.9 \pm 0.4$ & $2.3 \pm 0.9$ & $5.0 \pm 1.5$ \\
\hline
\end{tabular}

\section{$5 \mathrm{~L}$ 발효조 배양}

최적화 배지의 산업적 유용성을 평가하기 위하여 $5 \mathrm{~L}$ 발효조(Kobiotech, Incheon, Korea)를 사용하여 L. plantarum 를 배양하였다. Working volume을 $4 \mathrm{~L}$ 로 제조하였다. MRS 액체배지에 접종하여 전 배양 시킨 유산균을 $10 \%$ 로 본 배양배지에 접종하였다. 배양온도 $37^{\circ} \mathrm{C}$, 교반속도 $180 \mathrm{rpm}$ 으로 24 시간 후 균을 채취하여 생균수를 확인하였다.

\section{결과 및 고찰}

\section{산업용 기본배지 조성}

산업 규모에서 배지의 가격대비 효율성을 높이기 위한 기본배지 조성 결정을 위해 탄소원과 질소원의 농도에 따른 유산균의 증식을 비교하였다. MRS 배지 조성을 기본화 한 후, 질소원을 $1 \%$ 로 고정하고, 탄소원인 glucose의 함량 은 $2 \%$ 에서 $1 \%$ 로 낮췃을 때 $3.9 \pm 0.6 \times 10^{8} \mathrm{CFU} / \mathrm{mL}$ 에서 $1.9 \pm 0.4 \times 10^{8} \mathrm{CFU} / \mathrm{mL}$ 로 유산균 증식률이 $52 \%$ 줄어들었다. 그러나 탄소원을 $1 \%$ 로 고정하고 질소원인 yeast extract을 $1.5 \%$ 에서 $0.5 \%$ 로 줄여도 질소원에 의한 변화는 $1.9 \pm 0.4 \times$ $10^{8} \mathrm{CFU} / \mathrm{mL}$ 와 $2.3 \pm 0.9 \times 10^{8} \mathrm{CFU} / \mathrm{mL}$ 로 질소원에 의한 유산 균 증식률의 변화는 없었다. 이러한 결과를 통해 본 조건하 에서 유산균의 증식에는 탄소원의 영향이 큰 것으로 판단하 여, 질소원의 함량을 $0.5 \%$ 로 줄이는 기본배지 조성 Test 4 를 기본배지 조성으로 결정하였다. 
유산균 배양에 따른 $\mathrm{pH}$ 및 유산균 증식능 변화

유산균 배양 중 $\mathrm{pH}$ 변화에 따른 유산균 증식능의 변화를 알아보기 위해 $\mathrm{pH}$ 를 조절하지 않은 기본 배지, 암모니아수 로 $\mathrm{pH} 5.0$ 를 조절한 기본배지 및 $\mathrm{pH}$ 를 조절하지 않은 미역 첨가배지에 대하여 배양 $0,6,12,18,24$ 시간에 $\mathrm{pH}$ 및 흡광도를 측정하였다.

그 결과, $\mathrm{pH}$ 를 조절하지 않은 기본 배지의 경우 $\mathrm{pH}$ 가 배양 6시간까지 급격히 저하되고, 12 시간 이후 $\mathrm{pH}$ 가 4 이하까지 떨어지는 것을 확인할 수 있었다. 배양 12 시간이 전에는 유산균의 증식을 나타내는 흡광도 값이 지속적으로 증가하였으나, $\mathrm{pH}$ 의 저하는 생육 저해로 이어져 배양 12 시 간 이후에는 더 이상의 흡광도의 증가 없이 일정한 수준에 머무는 것을 관찰할 수 있었다.

반면, 배양 중 $\mathrm{pH}$ 5로 유지한 배지에서 균의 증식은 지속 적으로 이루어져 관찰최종 시간인 배양 24 시간에는 흡광도 23 의 값이 관찰 되었다.

미역첨가 배지의 경우, $\mathrm{pH}$ 유지를 위한 알칼리용액의 첨가없이도 12 시간 배양 후에 $\mathrm{pH}$ 는 4.9 에서 4.1 까지 유지 되었으며, 유산균의 증식도 계속 이루어져 흡광도 값은 15 에서 23 까지 증가되는 것을 확인할 수 있었다. 이러한 결과 는, 인위적으로 $\mathrm{pH}$ 를 5 로 조절한 기본배지 결과와 유사하 다(Fig. 1).

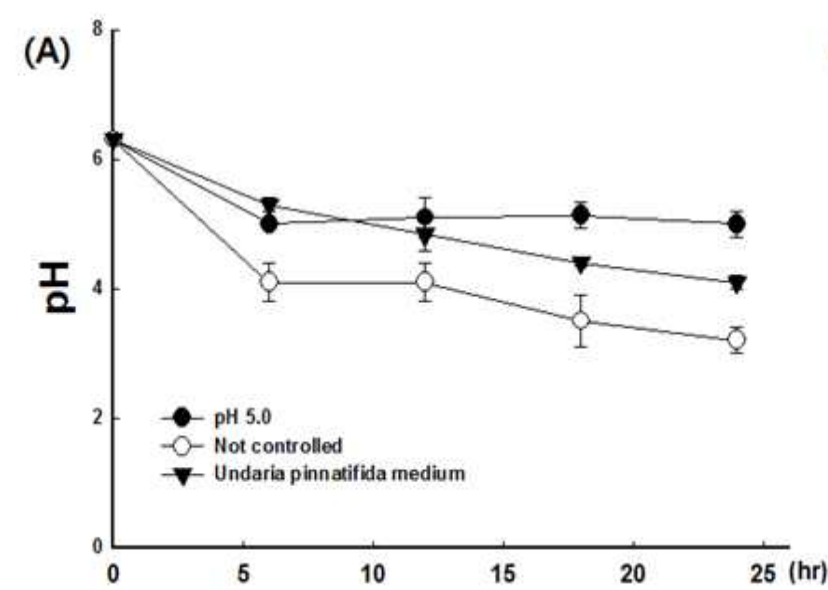

이 배양됨을 확인하였다(Table 2). 미역착즙액의 경우, 1 , $5,10 \%$ 농도의 착즙은 유산균 증식에 있어 농도의존적인 효과가 나타나지 않았다. 미역 분말을 농도별로 첨가한 배지 중, $0.5 \%, 1 \%$ 와 $1.5 \%$ 첨가시에는 각각 $12.6 \pm 1.7$,

Table 2. Effects of different methods of extracting U.pinnatifida on the growth of $L$. plantarum in a basal medium

\begin{tabular}{ccc}
\hline $\begin{array}{c}\text { Undaria pinnatifida extract } \\
\mathrm{CFU} / \mathrm{mL}\left(10^{8}\right)\end{array}$ & $30 \mathrm{~min}$ & $60 \mathrm{~min}$ \\
\hline $60^{\circ} \mathrm{C}$ & $7.5 \pm 0.4$ & $5.5 \pm 0.4$ \\
\hline $80^{\circ} \mathrm{C}$ & $11 \pm 0.8$ & $4.8 \pm 0.2$ \\
\hline
\end{tabular}

Table 3. Effect of $U$. pinnatifida juice on the growth of $L$. plantarum in a basal medium

\begin{tabular}{cccc}
\hline Undaria pinnatifida juice & $1 \%$ & $5 \%$ & $10 \%$ \\
\hline $\mathrm{CFU} / \mathrm{mL}\left(10^{8}\right)$ & $36.3 \pm 1.8$ & $35.2 \pm 0.2$ & $34.4 \pm 2.7$ \\
\hline
\end{tabular}

Table 4. Effect of $U$. pinnatifida powder on the growth of $L$. plantarum in a basal medium

\begin{tabular}{ccccc}
\hline Undaria pinnatifida powder & $0.5 \%$ & $1 \%$ & $1.5 \%$ & $2 \%$ \\
\hline $\mathrm{CFU} / \mathrm{mL}\left(10^{8}\right)$ & $12.6 \pm 1.7$ & $14.8 \pm 3.4$ & $18.1 \pm 2.8$ & $0.1 \pm 0.04$ \\
\hline
\end{tabular}

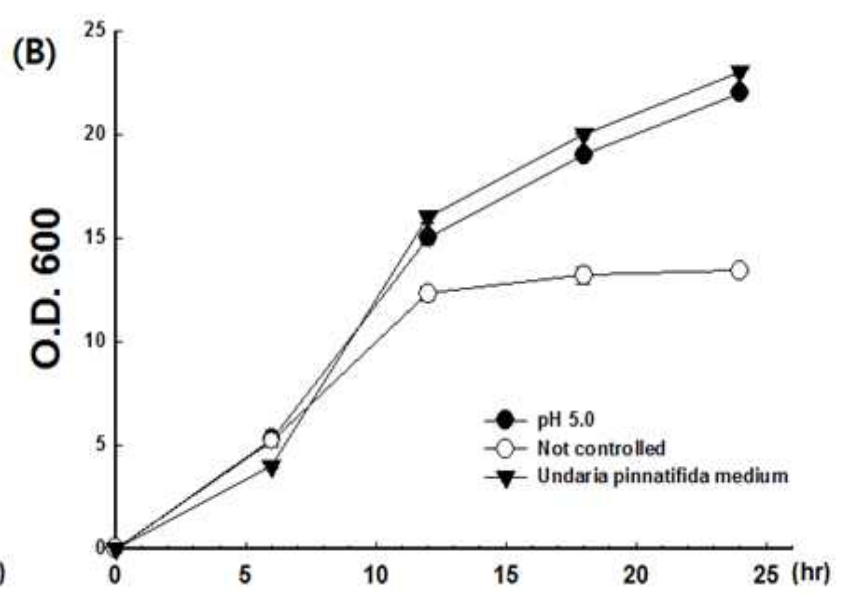

Fig. 1. Effects of U.pinnatifida in the $\mathrm{pH}$-stat controlled $5 \mathrm{~L}$-jar cultivation of $L$. planatarum.

미역의 전처리 방법에 따른 유산균 증식능

산업적 이용을 위해 $5 \mathrm{~L}$ 발효조에 기본배지를 바탕으로 미역의 첨가방법에 따른 유산균의 증식능을 확인하고자 미역을 추출, 착즙, 분말 상태로 기본배지에 첨가하고 유산 균을 배양 후 유산균수를 측정하였다.

$1 \%$ 미역 추출의 조건을 $60^{\circ} \mathrm{C}$ 에서 30,60 분 그리고 $80^{\circ} \mathrm{C}$ 에 서 동일 시간으로 설정하고 유산균 증식에 미치는 영향을 평가하였다. 그 결과 추출시간에 따른 유산균 증 식능의 변화는 관찰되지 않았으며, $80^{\circ} \mathrm{C}, 30$ 분 조건에서 추출 후 제조된 배지에서 $11 \pm 0.8 \times 10^{8} \mathrm{CFU} / \mathrm{mL}$ 로 가장 많은 유산균
$14.8 \pm 3.4$ 과 $18.1 \pm 2.8\left(10^{8} \mathrm{CFU} / \mathrm{mL}\right)$ 의 유산균 증식을 나타내 었으나, $2 \%$ 로 첨가된 배지에서는 사용된 다른 농도에 비해 100 분의 1 수준으로 증식능 저하되는 현상이 관찰되었다 (Table 4). 미역 첨가 비율 $1 \%$ 를 기준으로 $80^{\circ} \mathrm{C}, 30$ 분 추출, 착즙, 분말 첨가 배지의 유산균수를 비교해 보았을 때 각각 $11.0 \pm 0.8,36.3 \pm 1.8$ 과 $14.8 \pm 3.4\left(10^{8} \mathrm{CFU} / \mathrm{mL}\right)$ 로 착즙으로 배 지에 첨가시 가장 많은 유산균 수를 나타내었다(Fig. 2).

유산균 중에서, 김치 발효 등에 많이 관여하는 것으로 알려져 있는 L. plantarum은 생육효율과 젓산 생산량이 우 수하여 생균제 균주로 널리 이용되고 있다(8). 그러나 유산 
균 생산 배지는 다른 균종에 비하여 가격이 비싸므로 유산 균을 다양한 산업적 분야에 널리 보급하는 데 제한요인이 될 수 있다. 실제로 생균제의 효과적이고 경제적인 이용을 위해서는 최적 배지 조성의 결정이 매우 중요하다(9). 미생 물을 이용한 발효과정의 생산성은 배지의 영양성분에 따라 서 그 효율이 달라지기 때문에 탄소원, 질소원 그리고 무기 물원을 포함하는 배지성분의 경제적 도출은 발효의 생산성 에 있어 매우 중요한 요인으로 작용한다(10). 이러한 경제적 배지의 도출을 위하여 다양한 방법들이 개발되어 왔다 (11-13).

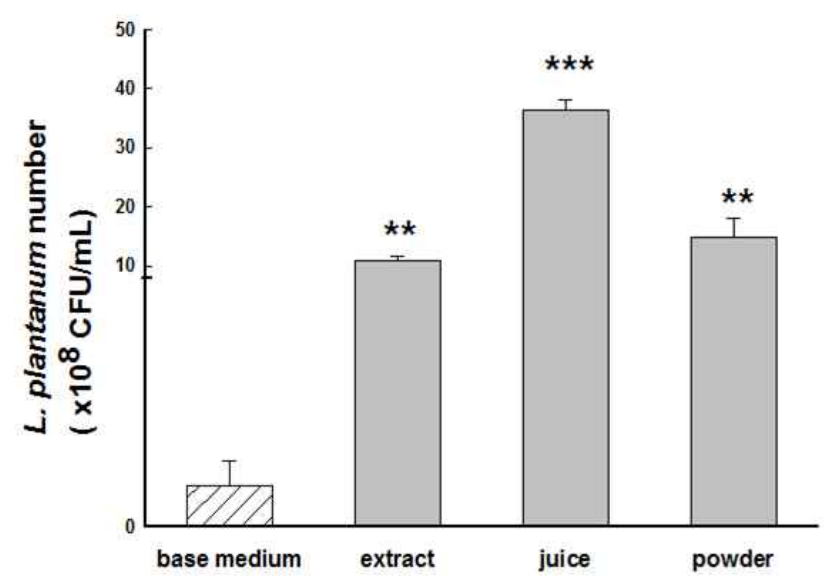

Fig. 2. Effect of $U$. pinnatifida on the growth of $L$. plantarum in a basal medium.

The values were presented as mean $\pm \mathrm{SD} * * \mathrm{p}<0.01, * * * \mathrm{p}<0.001$ significantly different from the untreated group.

본 연구에서도 단가가 낮으면서 유산균 배양이 충분이 이루어져 산업적 규모로 활용이 가능한 배지를 개발하고자 하였다.

기본 배지는 탄소원으로 glucose, 질소원으로 yeast extract, 무기염류로는 ammonium sulfate를 활용하여 선정 하였다(Table 1). 탄소원을 포함하는 유산균 배양용 배지 조성물에 있어서, 균주가 성장하는 동안 탄소원 으로부터 전환된 유산, 초산, 개미산 등에 의해 배양액의 $\mathrm{pH}$ 가 저하 되며, 균체 성장에 영향을 미치게 된다. 이를 보완하기 위해 서는 pH-stat 조절 방식으로 화학물질을 투입하여 일정한 $\mathrm{pH}$ 를 유지시켜 균체를 배양한다(14-16). 하지만, 유산균은 균체를 동결건조하여 바로 제품화하기 때문에 $\mathrm{pH}$ 조절에 사용되는 화학물질의 종류나 사용량이 제한적이다. 특히, 염기성 화학물질의 추가 첨가는 유산균의 발효 식품으로의 이용이라는 기능적 용도에 결코 바람직하지 않은 문제가 있다.

그렇기 때문에 본 연구에서는 식품으로 이용이 가능한 알칼리 성분의 해조류를 활용하여 유산균 배양배지를 제조 하였다. 해조류는 바이오매스가 풍부한 해양생물자원으로
알려져 있으며, 대량 양식 기술의 개발로 수산물 생산량의 약 $20 \%$ 를 차지하고 있다. 해조류는 식용, 약용 사료 또는 해조공업의 원료로 이용되어왔으며, 종류 또한 갈조류 135 종 남조류 48종, 홍조류 355종으로 다양하다. 이중 식생활 에 이용되는 종류는 약 70종이며, 가장 흔히 이용되고 있는 해조류 중 갈조류에 속하는 미역은 $100 \mathrm{~kg}$ 당 단백질 6.8 $\mathrm{kg}$, 당질 $43.8 \mathrm{~g}$ 섬유질 $7.5 \mathrm{~g}$ 칼슘을 함유 하고 있다 $(5,6,17,18)$. 또한 김, 미역, 다시마의 $\mathrm{pH}$ 를 측정해 보았을 때 미역이 가장 높은 $\mathrm{pH}$ 를 나타냄에 따라 미역을 유산균 배양 배지의 첨가물로서 선정하였다.

미역의 최적의 첨가 방법을 찾고자 추출, 착즙, 분말의 형태로 배지를 제조하여 유산균 증식능을 평가하였을 때 미역의 첨가를 통해 $\mathrm{pH}$ 의 보정없이 유산균 증식능이 증가 되는 것을 확인하였으며 이러한 실험 결과를 통해, 폐기되 어 환경오염원이 되는 가식부 외 미역부분을 첨가함으로서 종래 $\mathrm{pH}$ 조절을 위해 완충액으로 첨가되는 합성 화학물질 을 대체하여 활용될 수 있음을 확인하였다.

미역을 활용한 최적화 배지의 산업용 활용을 위해 $5 \mathrm{~L}$ 발효조를 이용하여 L. plantanum을 배양하였을 때, 따로 $\mathrm{pH}$ 조절이 필요 없이도 균체 성장 및 $\mathrm{pH}$ 가 암모니아수를 통해 $\mathrm{pH}$ 를 5.0으로 유지시킨 시험군과 비슷하게 유지되는 결과를 확인하였다.

미역첨가 기본배지 선정에 따라 산업용으로 사용되어지 는 배지 단가를 2.4 배 절감효과와 높은 균체 수율 등 충분한 경제적 장점을 기대할 수 있다. 이러한 연구결과는 미역을 유산균 배양에 이용함으로써 해조류의 식이섬유 등이 갖는 정장작용에 유산균이 시너지 효과를 나타낼 뿐만 아니라 폐기되는 천연 식물자원을 활용함으로써 새로운 부가가치 창출과 환경오염을 예방하는 효과를 기대할 수 있다.

\section{요 약}

산업적 유산균 배양의 가격대비 효율성을 높이기 위하여 질소원, 탄소원 및 무기염물을 기본량으로 기본배지를 제 조하고, 효율적인 고농도 유산균체를 수득하기 위하여 $\mathrm{pH}$ 조절제로서 따로 첨가되어지는 합성 화학물질을 대신하여 미역을 실험에 사용하였다. 미역의 최적의 첨가 방법을 찾 고자 추출, 착즙, 분말의 형태로 배지를 제조하여 유산균증 식능 평가한 결과, 착즙의 형태에서 유산균 증식능이 가장 큰 것으로 확인되었다. 이러한 실험 결과를 통해, 폐기되어 환경오염의 원인이 되는 가식부 외 미역을 유산균 배양배지 에 착즙형태로 첨가함으로서 종래 $\mathrm{pH}$ 조절을 위해 완충액 으로 첨가되는 합성 화학물질을 대체하여 활용될 수 있음을 확인하였다. 또한 미역첨가 기본배지 선정에 따른 배지 단 가를 절감하면서 높은 균체 수율을 얻는 등 충분한 경제적 장점을 기대할 수 있다. 이러한 연구결과는 미역을 이용함 
으로써 배양 시 해조류의 식이섬유 등이 정장작용에 유산균 의 시너지 효과뿐만 아니라 폐기되는 천연 식물자원을 활용 함으로써 새로운 부가가치 창출과 환경오염을 예방하는 효과를 기대할 수 있을 것이다.

\section{감사의 글}

본 연구는 “산업통상자원부”, “한국산업기술진흥원”, “호남지역사업평가원"의 “광역경제권 선도산업 육성사 업” R0002194로 수행된 연구결과입니다.

\section{References}

1. Vijayakumar M, Ilavenil S, Kim DH, Arasu MV, Priya $\mathrm{K}$, Choi KC (2015) In-vitro assessment of the probiotic potential of Lactobacillus plantarum KCC-24 isolated from Italian rye-grass (Lolium multiflorum) forage. Anaerobe, 32, 90-97

2. Shen X1, Yi D, Ni X, Zeng D, Jing B, Lei M, Bian Z, Zeng Y, Li T, Xin J (2014) Effects of Lactobacillus plantarum on production performance, immune characteristics, antioxidant status, and intestinal microflora of bursin-immunized broilers. Can J Microbiol, 60, 193-202

3. Ha DM (2002) Food microbiology. Shinkwang Publishing Co, Seoul, Korea, p 221-272

4. Christian C, Madec MN, Patrick B (1992) Production of concentrated Bifidobacterium bifidum J Chem Technol Biotechnol, 53, 189-198

5. Open U, Thames $\mathrm{P}$ (1992) The effect $\mathrm{pH}$ on growth. In vitro cultivation of microorganisms, Jordan Hill, Utterworth-Heinemann Ltd Linacre House, Oxford, UK, p 35-36

6. Kim KH, Kim CS (1982) Studies on the manufacture of Underia pinnatifida laver and it's physicochemical properties - I. Histochemical properties. Korean J Food Sci Technol, 14, 336-341

7. Kim HS (2004) Studies on extracts processing of a by-products of Undaria pinnatifida and growth response to horticultural crops treated with seaweed materials. MS Thesis, Sunchon National University, Korea, p 36-38
8. Erdene G, Eom HJ, Kim BS, Ko JH, Han NS (2011) Mannitol production by Leuconostoc citreum KACC 91348P isolated from kimchi. J Microbiol Biotechnol, 21, 968-971

9. Gao X, Qiao S, Lu W (2009) Determination of an economical medium for growth of Lactobacillus fermentum using response surface methodology. Lett Appl Microbiol, 49, 556-561

10. Hauhan K. Trivedi U, Patel KC (2007) Statistical screening of medium components by Plackett-Burman design for lactic acid production by Lactobacillus $s p$. KCP01 using date juice. Bioresour Technol, 98, 98-103

11. Abdel-Fattah Y (2002) Optimization of thermostable lipase production from a thermophilic Geobacillus $s p$. using Box-Behnken experimental design. Biotechnol Lett, 24, 1217-1222

12. Bas D, Boyaci I (2007) Modeling and optimization I : usability of response surface methodology. J Food Eng, 78, 836-845

13. Chhaya U, Gupte A (2010) Optimization of media components for laccase production by litter dwelling fungal isolate Fusarium incarnatum LD-3. J Basic Microbiol, 50, 1-9

14. Adamberg K, Kask S, Laht TM, Paalme T (2003) The effect of temperature and $\mathrm{pH}$ on the growth of lactic acid bacteria : a pH-auxostat study. Int J Food Microbiol, 85 171-183

15. Herbert D, Elsworth R, Telling R C (1956) The continuous culture of bacteria; a theoretical and experimental study. J Gen Microbiol, 14, 601-622

16. Janet R Stein (1975) Handbook of phycological methods, culture Methods and growth measurements. Cambridge University Press 8, 24-48

17. Takai M, Miyazaki Y, Tachibana H, Yamada K (2014) The enhancing effect of fucoidan derived from Undaria pinnatifida on immunoglobulin production by mouse spleen lymphocytes. Biosci Biotechnol Biochem, 78, 1743-1747

18. Itoh M, Kashiwagi M, Arimochi H, Morita K (2012) In vitro cytotoxic effect of ethanol extract prepared from sporophyll of Undaria pinnatifida on human colorectal cancer cells. Phytother Res, 26, 191-196 